\title{
ÇORUM-SUNGURLU YÖRESİ AŞAĞI FINDIKLI KÖYÜ GELENEKSEL KADIN KIYAFETLERINDE RENKLERİN DİLİ ÜZERINE BİR İNCELEME
}

\author{
AN INVESTIGATION ON THE COLORS IN TRADITIONAL WOMEN'S \\ CLOTHING AT THE ASAGI FINDIKLI VILLAGE OF CORUM-SUNGURLU \\ REGION
}

\section{ИССЛЕДОВАНИЕ ЯЗЫКОВЫХ ОСОБЕННОСТЕЙ В РАСЦВЕТКАХ ОДЕЖДЫ ЖЕНЩИН ИЗ СЕЛА АШАГЫ ФЫНДЫКЛЫ ЧОРУМ- СЮНГЮРСКОГО РАЙОНА}

\author{
Gamze KARAMAN* - Deniz GÜMÜŞ ${ }^{* *}$ - Kudret Safa GÜMÜŞ***
}

\section{ÖZ}

Anadolu'da geleneksel kadın kıyafetlerinin kökeni çok eskilere dayanmaktadır. Geleneksel motifler ile süslenen, kullanılan renkler ile bireyin duygu ve düşüncelerini yansıtan kadın kıyafetleri, ait olduğu yöreye özgü şekilde gelişmiş olup, her bölgede farklı özellikler göstermiştir. İnsanoğlunun inanç, gelenek ve kültürlerini en iyi yansıtan giyim olgusu, geçmişten günümüze kadar değişerek ve gelişerek varlığını sürdürmüştür. Anadolu'da çeşitlilik gösteren, kültürel değerlerimizden biri olan, her yörede farklılık gösteren geleneksel kadın kıyafetleri oldukça dikkat çekmektedir. Farklı bölgeler arasındaki bu çeşitlilik ve renklilikler, yöresel kıyafetlerde ön plana çıkmaktadır.

Araştırmanın kapsamı, Çorum ili Sungurlu ilçesine bağlı Aşağı Fındıklı Köyü ile sınırlıdır. Çalışmada, yöreye ait geleneksel kadın kıyafetleri; süsleme, kullanım alanları ve renk özellikleri ile birlikte incelenerek yöreye ait giysilerin önemi ortaya konulmuştur. Söz konusu geleneksel kıyafetler; "yazma, yelek, elbise, şalvar ve önlük” olarak karşımıza çıkmakta, bu kıyafetlerin ise eskiye nazaran çok tercih edilmediği, sadece özel günlerde giyildiği ve sandıklarda muhafaza edildiği tespit edilmiştir. Bu çalışma, yörenin kültürünü giysi bağlamında tanıtmada önem arz etmektedir.

Anahtar Kelimeler: Kültür, Kadın Giyimi, Renk, Çorum, Aşağı Fındıklı Köyü.

\section{ABSTRACT}

Theorigins of traditional women's clothes in Anatolia are based on very old ones. The women's clothing, which is decorated with traditional motif sand reflects the feelings and thoughts of the individual with the colors used, developed in a locally specific way and belongs to different regions. The clothing, which best reflectst beliefs, traditions and cultures of mankind, maintain sits existence bychanging and developing from day to day.Traditional women's clothes vary in Anatolia, one of our cultural values, and differ in

* Öğr. Gör., Aksaray Üniversitesi Güzelyurt Meslek Yüksekokulu karamangamze3@gmail.com

** Öğr. Gör., Aksaray Üniversitesi Güzelyurt Meslek Yüksekokulu denizgumus@aksaray.edu.tr

*** Okutman, Aksaray Üniversitesi Şereflikoçhisar Berat Cömertoğlu Meslek Yüksekokulu kudretsafagumus@aksaray.edu.tr.

10.17498/kdeniz.279650 
each region. These diversities and colors between different regions are at thefore front of regional dresses. The scope of the survey is limited to the Asag1 Findikli village of Sungurlu district of Corum province. In the study, traditional women's clothing belong into the region; Ornamentation, usage are as and color characteristics of the region.The traditional clothes; "Writing, vest, dress, shalwarandapron" are confronted, these clothes are not preferred much compared to the old one, the are only worn on special occasions and kept in boxes. This study is important to introduce in the context of the culturally dressing of the region.

Key words: Culture, Women Dress, Color, Corum, Asagı Findıklı Village.

\section{АННОТАЦИЯ}

В статье исследована традиционная одежда женщин села фындыклы из ЧорумСюнгюлского района. Разные рассцветки, укращения, особенности применения указывают на оригинальность и значение местного сомобытия. В основном встречается одежда следующими названиями “язма, елек, елбисе, шалвар, ёнлюк”. Она. в основном, применяется в особых случаях и хранится в сундуках. Статья ориентирована на ознакомление местной культуры.

Ключевые слова: культура, женская одежда, цвета, Чорум, село Ашаги Фындыклы.

\section{GíRİŞ}

Giyim, insanlık tarihi kadar eski olup örtünme ihtiyacından doğarak gelişmiştir. İnsanoğlu giyim unsuru olarak ilk önce bitkileri kullanmış, sonra avladıkları hayvanların postlarını kullanarak kendilerini dış etkenlerden korumaya çalışmışlardır. Daha sonra ise giyim, farklı kültürler arasında din, inanç, örf, adet, gelenek ve göreneklerle beslenerek şekillenmiştir.Giyim; bir halkın kültür, gelenek, inanç ve yaşayış biçimi hakkında bilgiler veren önemli kaynaklar olarak karşımıza çıkmaktadır.Anadolu'da, giyim tarihi çok eskilere dayanmakta olup, kadın-erkek kıyafetleri sosyal- siyasi ve ekonomik yönden etkileşim içinde oldukları uygarlıklar aracılığı ile şekillenerek günümüze kadar gelmiştir.

Anadolu giyiminde bazı ortak özellikler olsa da giyim biçimleri bölgelere göre farklılık göstermektedir. Bu farklılık kadın giyiminde daha belirgindir. Bunun başlıca nedenleri; yöresel gelenekler, kişisel beğeniler, bölgenin çevre ile komşuluk durumları, iklim özellikleri, tarihsel nedenlere dayalı kültür birikimi, etnik grupların varlığı ve sosyoekonomik yapıdır (Tezcan 1983:264).

Kadınların giymiş olduğu geleneksel kıyafetlerde kullanılan renk, biçim ve motif yöre insanının yaşam tarzı hakkında bizlere ip ucu vermiştir. Giyim, sözsüz iletişimimde de duyguları ifâde etme aracı olarak son derece önemli rol oynamaktadır. Renkler, motifler, giyinme biçimleri ve aksesuar üzerinde imgelenen giyim olgusu toplumda kişinin hangi konumda olduğunun belirlenmesi açısından önemlidir. Giyim ayrıca duyguların gerçekçi bir şekilde yansıtılmasında da etkili olmaktadır. Bu sayede toplumların, düşünce tarzları ve değer yargıları hakkında çıkarımlarda elde edilebilmektedir. Özellikle renk olgusu; tarih boyunca medeniyetlerin sosyal, kültürel ve sanatsal ifâde aracı olarak kullanılmış olup giyim-kuşam kültüründe de etkin bir rol oynayarak duygu, düşünce ve inançları yansıtan bir simge hâline gelmiştir. Renk; sanatın bir unsuru olsa da farklı coğrafya ve kültürlerde değişik anlamlar taşıyabilen bir dışavurum aracıdır. 
Renklerin insan psikolojisi ve davranışları üzerinde önemli etkileri olduğu kabul edilmektedir. Nitekim sevilen renkler aynı zamanda bireylerin kişilik özelliklerini de ele vermektedir (Altıntaş 2001:137). Kişilerin tercih etmiş olduğu renkler, karşı tarafa iç dünyası hakkında bilgi verebilmektedir. Her renk insanda çeşitli duyguları yansıtmaktadır. Örneğin; kırmızı, enerji, hareket, güç, kuvvet ve dikkat veren; yeşil ve mavi, huzur; siyah, karamsarlık, yas ve resmiyeti barındıran; beyaz, saflığı, temizliği, duruluğu yansıtan; sarı, güneşi temsil eden renklerdir. Renkler, kişinin tercihlerine, sosyal ve kültürel şartlara, kişisel beğeni gibi birçok etkene bağlı olarak kişiden kişiye değişik anlamlar ifade edebilir.

Işığın etkisi ile değişik biçimlere bürünen, görme duyusu ile algıladığımız renk kavramı, Türk kültüründe duygu ve düşünceleri yansıtması açısından önemli bir rol üstlenmektedir. Renkler, gerek İslâm öncesi gerekse İslâm sonrasında, farklı toplum ve kültürlerde özel bir takım inançlar ve nesneleri simgeleştirmek için de kullanılmışlardır.

Anadolu'da bazı yörelerde geleneksel kıyafetler hâlâ özelliğini korumakla birlikte; değişen ve gelişen şartlara bağlı olarak varlığını kaybetmekte, bu nedenle bazı kıyafetler gelecek kuşaklara aktarılmak için sandıklar da muhafaza edilmektedir. Araştırmanın konusu, Çorum İli Sungurlu İlçesi-Aşağı Fındıklı Köyü odaklıdır. Kişilerle yapılan karşılıklı mülâkatlar sonucu, tespit edilen geleneksel kadın kıyafetleri; nitelik, kullanılan motif ve tercih edilen renklerin anlamsal özellikleri bakımından incelenmiştir.

Çalışmada, sahada yapılan yerinde inceleme-gözlem ve karşılıklı görüşme yöntemi kullanılmıştır.

\section{1.Çorum İli ve Sungurlu İlçesi Hakkında Genel Bilgi}

Çorum; Anadolu'nun iç kesimlerini Karadeniz kıyılarına bağlayan yollar üzerinde bulunan, Paleolitik Dönemden başlayarak yerleşime sahne olan, tarihin ilk organize devleti Hititlerin başkenti Hattuşaş'a ev sahipliği yapmış; Roma, Selçuklu, Osmanlı ve Cumhuriyet dönemlerinde yerleşim alanı olma özelliğini devam ettirmiş bir Anadolu kentidir (Günay 2007: 88).

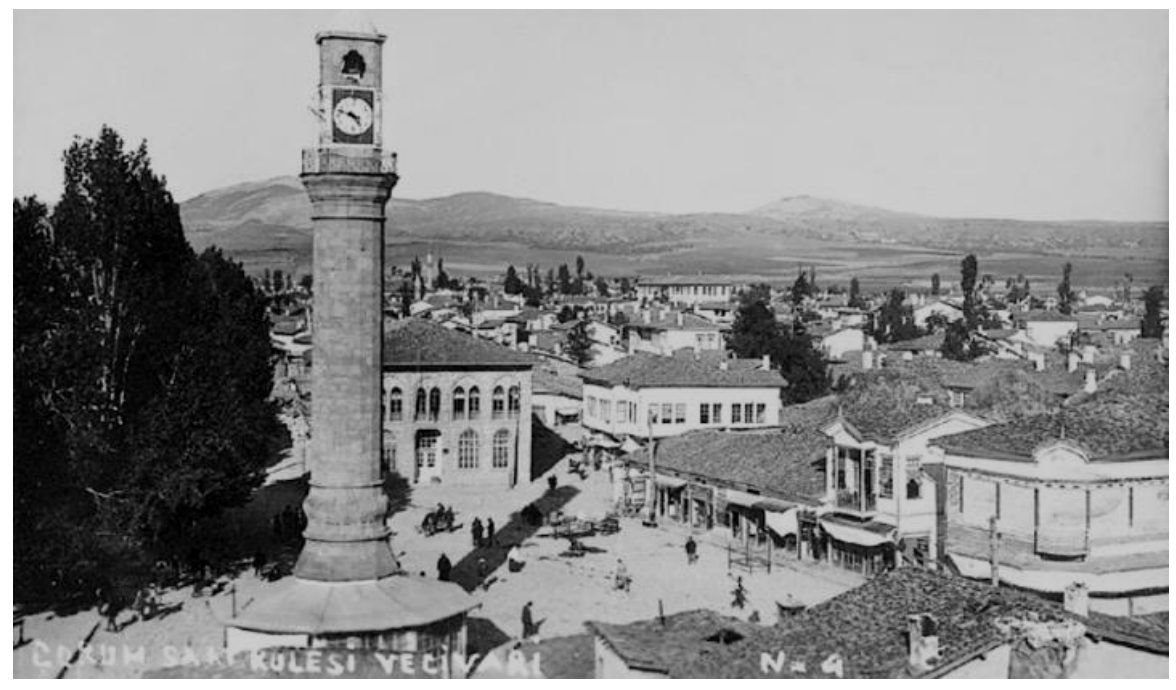

Fotoğraf:1 Çorum İli Genel Görünüm. 


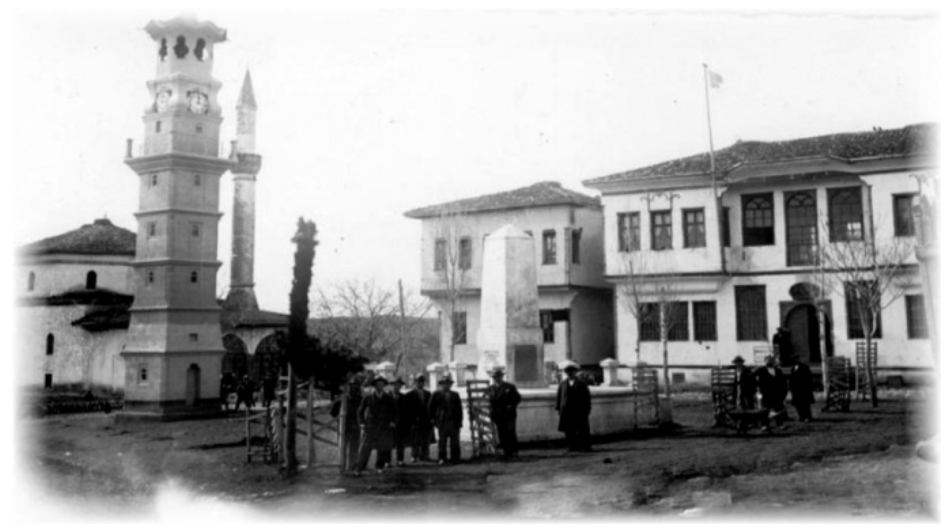

Fotoğraf:2 Sungurlu İlçesi Genel Görünüm. ${ }^{1}$

Sungurlu; İç Anadolu'da Çorum İli sınırları içinde yer alan bir ilçedir. Yöredeki ilk yerleşmeler M.Ö. 1800-M.Ö.1200 yıllarında Anadolu'da yaşayan yerli kavimlerden Hattiler bu bölgeyi önemli bir yerleşim merkezi hâline getirmiştir. Daha sonra bölgeye hâkim olan Hititler ise Hattuşa'yı (Boğazköy'ü) başkent yapmışlardır. Anadolu kapılarının Türklere 1071 Malazgirt Meydan Muharebesi ile açılmasından sonra Sungurlu ve yöresi Danişment Ahmet Gazi tarafından Bizanslılardan alınarak Türklerin idaresine ve egemenliğine geçmiştir. Sungurlu'nun adının ise Sunguroğlu Mehmet Bey'den aldığ1 rivâyet edilir (Evliya Çelebi 2006:185).

\section{Aşağı Fındıklı Köyü'nün Kuruluşu ve Tarihi Gelişimi}

Aşağı Fındıklı Köyü’nün kuruluşu 1800-1900 yılları arasında olduğu söylenmektedir. Tarihi araştırmalar ve bulunan bazı kalıntılardan elde edilen bilgilere göre; köy halkının geçmişi, Orta Asya'ya kadar uzanmaktadır. Köyün adının ise, her tarafının fındık ağaçları (yabanî) ile kaplı olmasında dolayı köye Fındıklı adı verildiği söylenmiştir (Mandıralıoğlu 2002: 11-12).

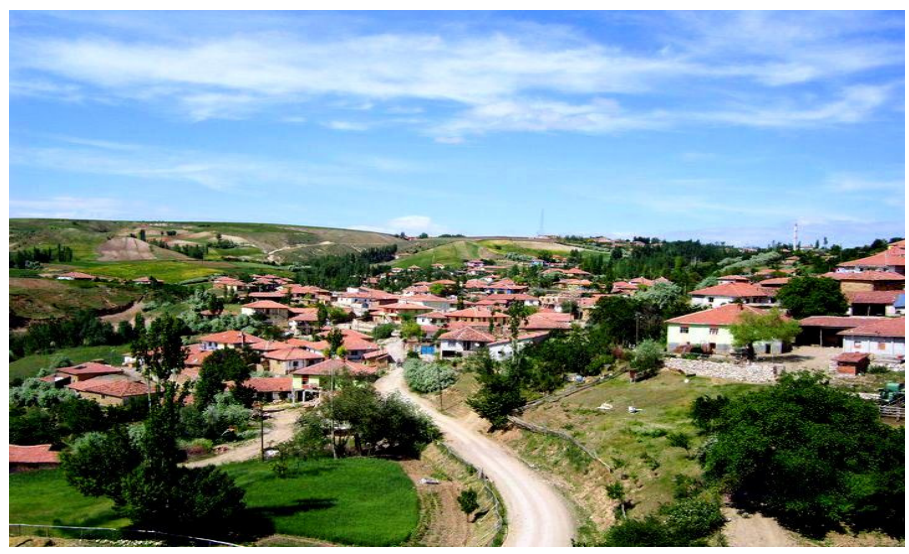

Fotoğraf No:3Aşağı Fındıklı Köyü Genel Görünümü 2009 .

${ }^{1}$ Bkz. Yiğit,İ.,,Tarihe Işık Tutan Çorum Fotoğrafları, (http://www.corum.com.tr). Çorum, 


\section{Aşağı Fındıklı Köyü Geleneksel Kadın Kıyafetlerinin Özellikleri}

Araştırmanın konusuna kaynak olanAşağı Fındıklı Köyü'nde, geçmişten gelen geleneksel giyim-kuşam zenginliği hemen göze çarpmaktadır. Kumaşların farklılığ1, süslemede kullanılan yöre ile deyimleşmiş motifler, çarpıcı renkler kadınların kıyafetlerini süslemiştir. Günlük, özel gün ve gecelerde giyilen, özgün değeri olan geleneksel giysiler büyükler tarafından saklanarak muhafaza edilmiştir. Yöre halkında bulunan ve günümüze ulaşan giysilerde tercih edilen renkler ve motifler yörenin kültürel zenginliğini gözler önüne sermektedir.

Yapılan incelemeler ve mülâkâtlar sonucu, kıyafetlerde kullanılan renk ve motifler; yörede yaşayan halkın inanç, düşünce ve sosyo-ekonomik yapısını ortaya koymaktadır. Kullanım amaçları, renk ve süsleme özellikleri bakımından incelenen giyim parçaları; elbise, şalvar, cepken, yelek, öynük, başörtüsü ve çorap olarak sınıflandırılmıştır.

\begin{tabular}{|l|l|l|}
\hline Baş Giyim Parçaları & Beden Giyim Parçaları & Ayak Giyim Parçaları \\
\hline Yazma-Keten & Elbise-Entari & Çorap \\
\hline & Yelek & \\
\hline & Şalvar & \\
\hline & Önlük-Kırmalı Öynük & \\
\hline
\end{tabular}

Tablo 1: Aşağı Fındıklı Köyü’nde İncelemeye Alınan Giyim Parçaları

Yazma: Yörede“keten” adıyla bilinen tülbent genç-yaşı bütün köy kadınları tarafından kullanılmaktadır. Pamuklu kumaştan yapılan kenarları tığ yardımı ile pulla süslenen "keten"de beyaz dışında başka bir rengin kullanılmadığı görülmüştür. Türk kültür ve inancında önemli bir yeri olan beyaz rengin, saflığı, masûmiyeti, temizliği, sadeliği simgelediği için tercih edildiğini ve beyaz renkten başka hiçbir rengi kullanmadıkları belirtilmiştir. Ayrıca yaşı bir hayli ilerlemiş olan kadınların kendilerinin diğerlerinden büyük olduğunu göstermek için beyaz renkten başka yazma takmadıkları ifade edilmiştir (Kaynak Kişi; Makbule Çırakoğlu).

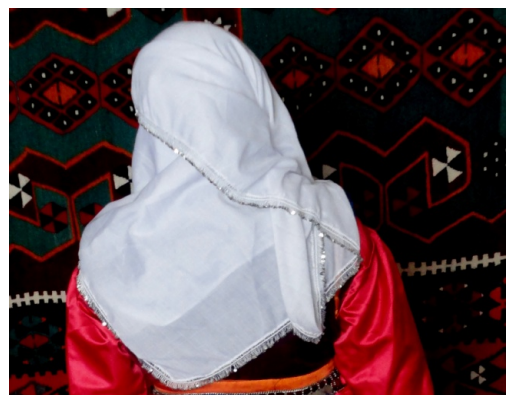

Fotoğraf No:4 Yazma “Keten”

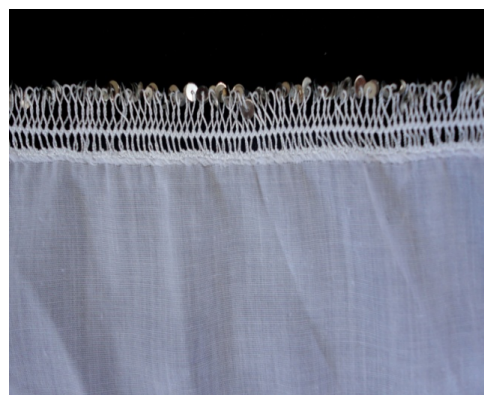

Fotoğraf No:5 Yazma “Keten” Detay Görünüm²

\footnotetext{
${ }^{2}$ Söz konusu fotoğraflar tarafımızca 14.06.2016 tarihinde çekilmiştir.
} 
Elbise (Entari): Basma, patiska ve buna benzer kumaşlardan yapılan uzun, düz, süssüz bir kadın kıyafetidir (Cremers1976:7712). Yörede; renklerine göre "mavili", "sarılı", "pembeli"olarak adlandırılan elbiselerde, bu renklerin dışında başka renge rastlanılmamıştır. Düz, ayak bileklerine kadar uzanan elbiseler saten ve simli parlak kumaşlardan dikilmiştir. Elbiseler, günlük ve özel günlerde giyilen kıyafetler olarak iki kısma ayrılmıştır. Simli parlak kumaştan dikilmiş olan kıyafetler genellikle özel günlerde, sade saten kumaştan dikilenler ise günlük kıyafet olarak tercih edilmektedir. Elbiselerde bu kadar canlı renklerin tercih edilmesi, köy halkının inançları ile örtüşmektedir. Yörede, sarı rengin güneş gibi parlaması ve etrafı aydınlattığına inanılmaktadır. Mavi rengin ise özgürlüğü ve kuşları anımsattığı ayrıca gökyüzü ve Allah arasındaki ilişkiyi kendilerine hatırlattığı söylenmiştir.

Altının rengini, merkezin hâkimiyetini ve gücü ifâde eden sarı, tarihte Türklerin sıkça kullandığı renklerden biri olmuştur. Öyle ki Türk sarısına "Altın Sarısı” denilmiştir (Bayat 1993:52).Mavi renk ise Türklerde; gökyüzü, su-deniz, aynı zamanda sonsuzluk ve huzurun rengidir (Uçar 2004: 53).Mavi genellikle gökrengi olarak kullanıldığı için Tanrı'nın ululuğunun ve yüceliğinin bir göstergesi olarak kabul edilmiştir. Bunun yanında Türk kültüründe gök, semavî bir kavram olarak; Gök Tanrl, gök kurt (Bozkurt), gök boynuzlu keçi, gök öküz,gök Türk, gök yüzlü Ŏ̆uz şekillerinde karşımıza çıkar. Yakut, Altay ve Manas destanlarında gök renginin sembolize ettiği değerler aynıdır (Bayat 1993: 5253).Gök Tanrı dinine inanan Türkler için gök mavidir. Şamanlarda ululuğu temsil eden mavi rengini, gök kelimesiyle adlandırmışlardır (Kafalı 1996: 50).

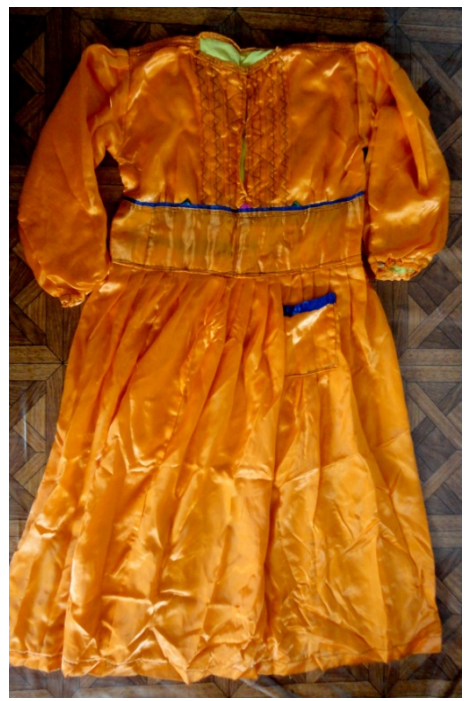

Fotoğraf No:6 Sarılı Elbise

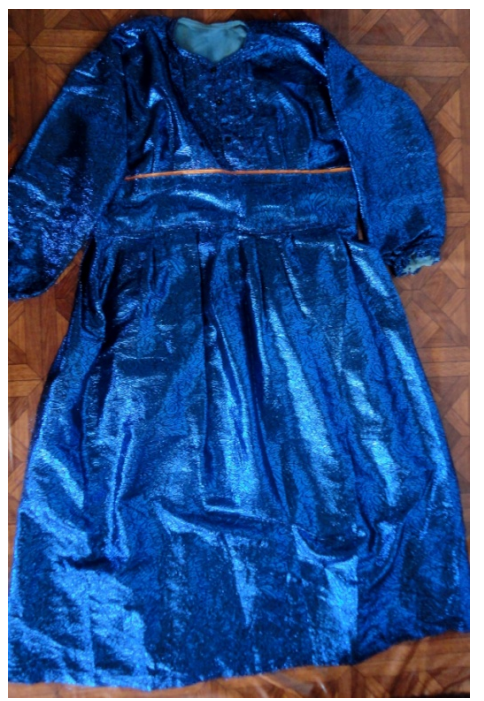

Fotoğraf No:7 Mavili simli elbise ${ }^{3}$

Yelek: Yelek; bazı yörelerde göynek olarak bilinen, özellikle kadınların sıklıkla tercih ettiği kısa veya uzun, kolsuz bir giyim parçası olarak tanımlanabilir. Yörede yapılan saha araştırmasında üç adet yelek incelenmiştir. Kadife kumaştan yapılan, düğün ve nişan gibi özel günlerde giyilen yeleğin uç kısımları gümüş liralar ile süslenmiş olup ekonomik

\footnotetext{
${ }^{3}$ Söz konusu fotoğraflar tarafımızca 14.06.2016 tarihinde çekilmiştir.
} 
durumu iyi olan kişilerin lira ile süslemeyi daha çok tercih ettiği belirtilmiştir. Yeleğin gögüs kısmında ise parlak simli yeşil bir kumaş tercih edilmiş, düğme ve pullarla yoğun süslemeler yapıldığı görülmüştür. Sarı ve pembe renkli yelekler ise daha çok günlük yaşamda tercih edilmiş, bu renkteki yeleklerde aşırı süslemeden kaçınılmıştır. Sarı, yaşamış ve yaşamakta olan tüm uygarlıklarda güneşi simgelemektedir. Yeşil rengin ise İslam inancında ayrı ve önemli bir yeri olmakla beraber huzuru, Nur'u ifade etmektedir.

Aynı zamanda yeşil renk verimliliği ve doğurganlığı simgeler ve Orta çağda gelinlerin yeşil giysi giydikleri söylenir (Halse 1978: 27-34).

Giyim parçalarında dikkati çeken unsur ise canlı renklerin seçimidir. Köy halkı tüm giyim parçalarında olduğu gibi canlı renkleri kullanmaktan çekinmemiştir. Bu renklerin kendilerine has olduğunu, başka hiçbir yörede olmadığı söylenmiştir. Canlı renklerin tercih edilme sebebini ise kadınların beğenisi olduğunu, kıyafetlerdeki renklerin kendilerine enerji ve canlılık kattığını ve her bir rengin kendileri için farklı anlamları olduğu ifâde edilmiştir (Kaynak Kişi; Melek Kalınsazoğlu).

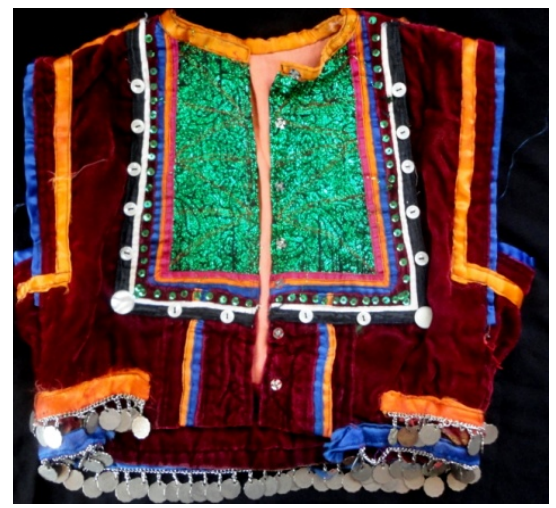

Fotoğraf No:8 Kadife Yelek

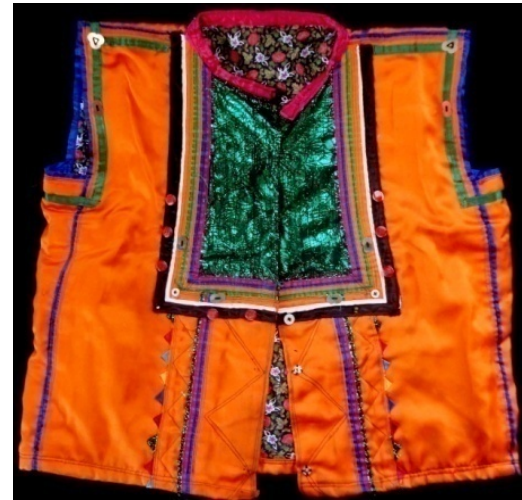

Fotoğraf No:9 Sarılı Yelek

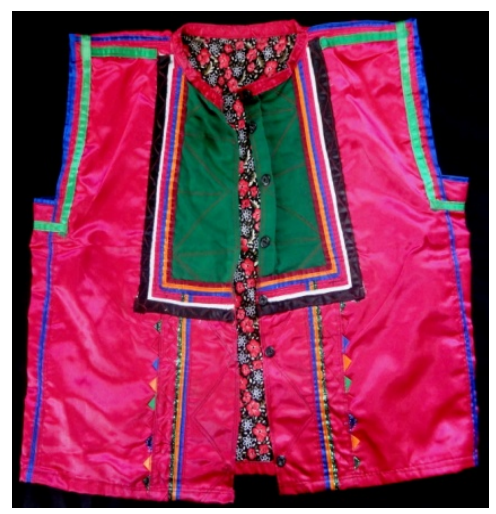

Fotoğraf No:10 Pembeli Yelek ${ }^{4}$

\footnotetext{
${ }^{4}$ Söz konusu fotoğraflar tarafımızca 14.06.2016 tarihinde çekilmiştir.
} 
Şalvar: Anadolu'da özelikle kırsal alanda giyilen, genellikle ağı çok bol olan, bele bir uçkur ile bağlanan geniş bir giyim parçasıdır. Şalvarların özelliklerine bakıldığında; kadife kumaştan, bol, dökümlü, canlı renklerin kullanıldığı ve bele gelen kısmın lastik ile tutturulduğu görülmektedir. Ayak bilek kısımları ise düz bırakılmıştır. Yörede ele geçen şalvarlarda kullanılan renkler; mor, yeşil, sarı, mavi, pembe ve yeşildir.

Mor; yaratıcılığı, özgürlüğü, duygusal bozukluğu, menekşeyi, tülü, patlıcanı, karamsarlığı anlatır. Güzellik simgesi olarak da kullanılmaktadır (Rayman 2002: 15). Yörüklerin ise ağırlıklı olarak yeşil, mor, kırmızı, sarı ve pembe rengi kullandıkları bilinmektedir. Türk kültüründe gerek yeşil cübbe, yeşil sarık ve türbelerin genellikle yeşile boyanması gibi uygulamalardan dolayı yeşil ruhanî bir renk olarak kabul edilmiş ve genellikle İslamiyet'in rengi olarak düşünülmüştür (Genç 1996: 42,Lings 2003: 48).Orta Asya'daki Türk köylü kıyafetlerinde ağırlıklı olarak mavi, kırmızı ve yeşilin hâkim olduğunu, aynı şekilde Hakas, Başkurt, Kırgız ve Azerî Türklerinin millî kıyafetlerinde de bu üç rengin kullanıldığını görürüz (Genç1997:66-69).

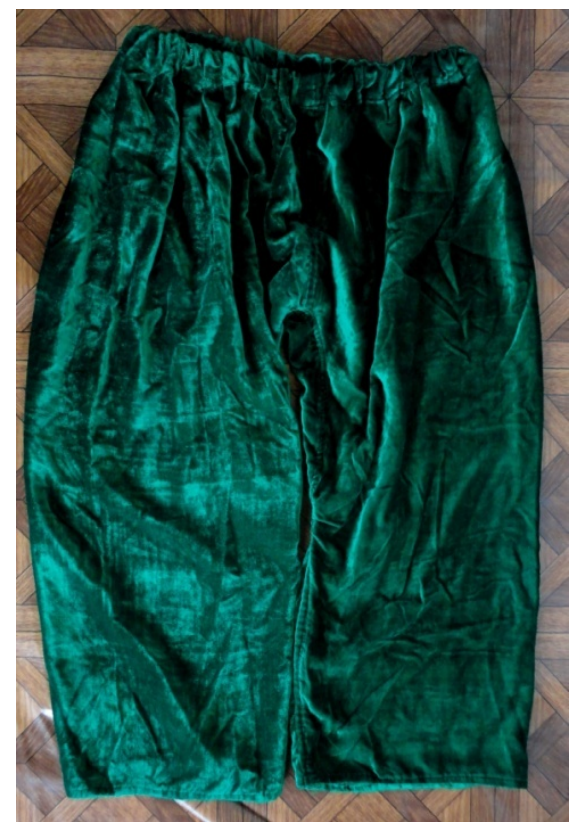

Fotoğraf No:11 Şalvar Genel Görünüm Fotoğraf No:12 Şalvar Genel Görünüm ${ }^{5}$

Önlük (KırmalıÖynük): Genellikle kadınların gündelik yaşamda iş yaparken elbiselerinin kirlenmemesi için giyilen üst giyim parçasıdır. Saten kumaştan dikilen önlükler gündelik yaşamda, parlak simli kumaştan dikilenler ise düğün ve nişan törenlerinde giyilmektedir. Önlükler genel özellikleri açısından incelendiğinde; kenarları firfırlı, cepli ve birbirine zıt üç-dört rengin tercih edildiği görülmüştür. Pembe simli kumaştan dikilen önlük özel günlerde giyilmekte olup mutluluğu, genç kızlığı, masumiyeti, kız çocuğunu ve pembe gülü ifâde ettiği belirtilmiştir (Kaynak Kişi:Melek Kalınsazlıoğlu).

Süsleme özellikleri açısından incelendiğinde ise yörede “idari” olarak bilinen gaz lambasının, kıyafetlere yansıtılması ve "muska" (üçgen) biçiminde simgelenmesi dikkat

\footnotetext{
${ }^{5}$ Söz konusu fotoğraflar tarafımızca 14.06.2016 tarihinde çekilmiştir.
} 
çeken önemli bir ayrıntıdır. Muska motifi, Anadolu'da yüzyıllardır kullanılan, inanç sisteminin gerektirdiği sembolik bir figürdür. Muska motifi sahibini, kötü olaylardan korumak amacıyla yazılmış olağanüstü gücü olduğuna inanılan bir tür tılsım olarak bilinir. Yörede; kötü bakışlara, bahtsızlığa, mutsuzluğa iyi geldiğini ve bunların etkisini azalttığı düşünülür.

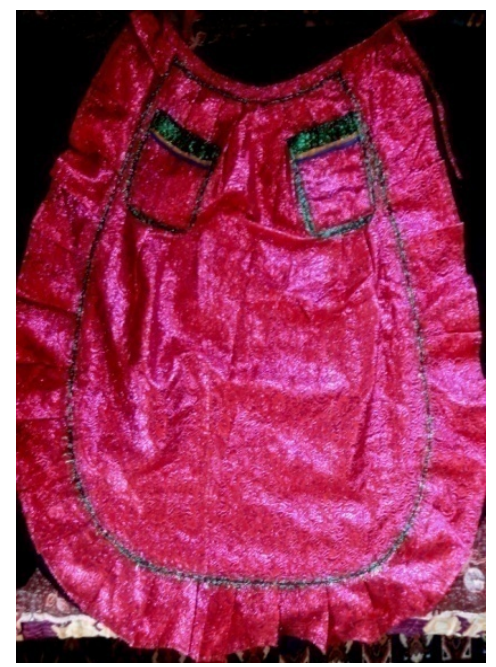

Fotoğraf No:13 Pembeli Önlük

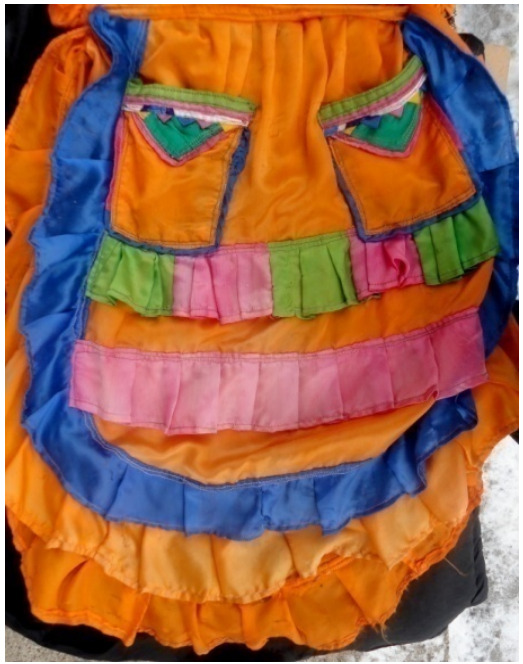

Fotoğraf No:14 Kırmalı Önlük

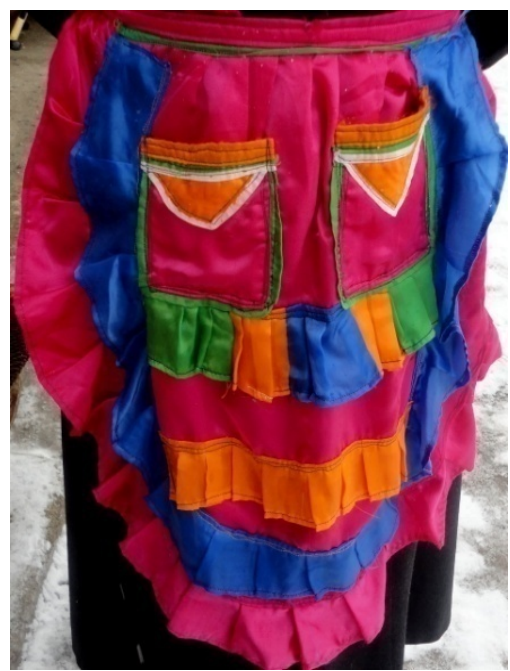

Fotoğraf No:15 Kırmalı Önlük ${ }^{6}$

Çorap: Giyim kuşamı tamamlayan pamuk veya ipekten örülmüş, uzun veya kısa konçlu ayak giyeceğine çorap denir (Şimşek, 1963/1964:3303). Kökboyası ile renklendirilmiş yün iplikten örülen çoraplar, genellikle diz hizasındadır. Ağırlıklı olarak kullanılan renkler; pembe, kırmızı, sarı ve beyazdır. Türk kültüründe kırmızı rengin gücü ve

${ }^{6}$ Söz konusu fotoğraflar tarafımızca 14.06.2016 tarihinde çekilmiştir. 
kudreti simgelemesinin yanı sıra bayrak rengi olmasından ötürü ayrı bir öneme sahiptir. Yörede ele geçen çoraplardaki desenler "elma şakl" ve "ekin kellesi" olarak isimlendirilmektedir. Elma şakı; bütün elmanın dörde bölünmesinden sonra ortaya çıkan dilimleri, çoraplarda motif olarak kullanma düşüncesini ortaya çıkarmıştır. Ekin kellesi ise yörede tarımla uğraşan halkın başaktan yola çıkarak isimlendirdikleri bir motiftir.

Halk kültürünün hemen her alanında elma, olağan ve olağanüstü yanıyla ele alınmış bir meyve olup Anadolu'da bolluk, bereket, üreme simgesidir (Altun2008:263).

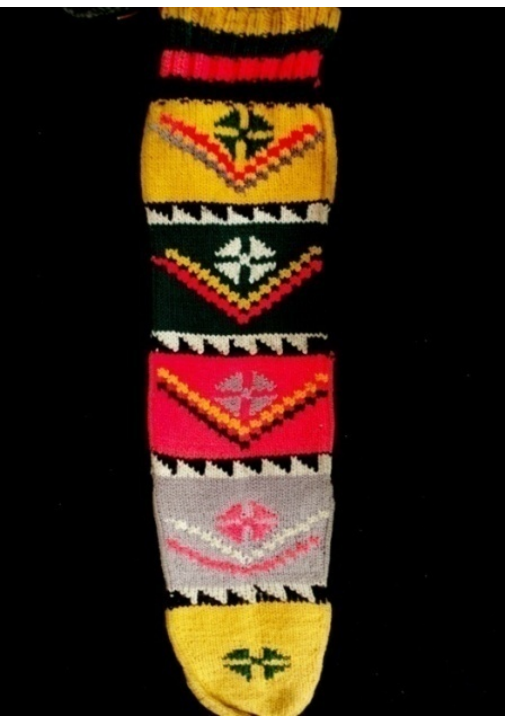

Fotoğraf No:16 "Elma şakı"

motifli çorap

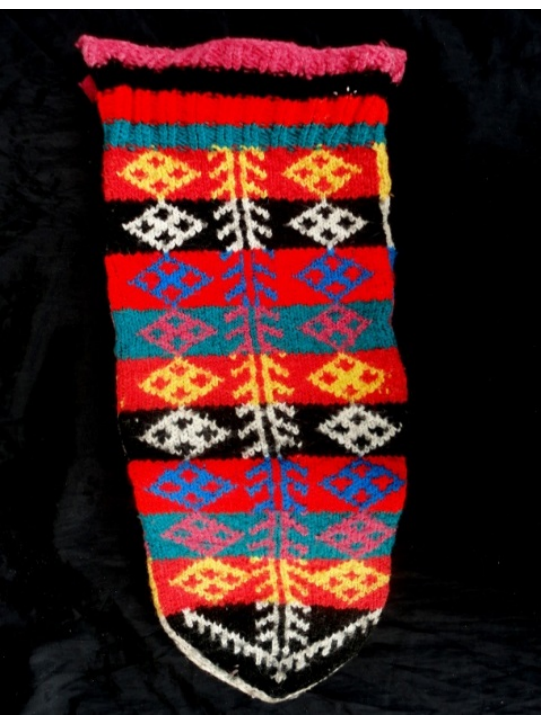

Fotoğraf No:17 "Ekin kellesi”

motifli çorap ${ }^{7}$

\begin{tabular}{|l|l|}
\hline \multicolumn{1}{|c|}{$\begin{array}{c}\text { Yöredeki Giyim } \\
\text { Parçaları }\end{array}$} & Giyim Parçalarının Yöredeki Tanımları ve Renkleri \\
\hline Yazma & $\begin{array}{l}\text { Keten olarak bilinir. Pamuklu kumaştan yapılan } \\
\text { kenarları tığ yardımı ile pulla süslenen ketende, beyaz } \\
\text { dışında başka bir renk kullanılmaz. }\end{array}$ \\
\hline Elbise-Entari & $\begin{array}{l}\text { Yörede; renklerine göre "mavili”, "sarılı", "pembeli” } \\
\text { olarak adlandırllan elbiseler vardır. Elbiseler, günlük } \\
\text { ve özel günlerde giyilen klyafetler olarak iki kısma } \\
\text { ayrılmıştır. }\end{array}$ \\
\hline Yelek & $\begin{array}{l}\text { Kadife kumaştan yapılan, düğün ve nişan gibi özel } \\
\text { günlerde giyilen yelek yörede karşımıza çımaktadır. } \\
\text { Sarı ve pembe renkli yelekler ise daha çok günlük } \\
\text { yaşamda tercih edilmiş, bu renkteki yeleklerde aşırı } \\
\text { süslemeden kaçınılmıştır. }\end{array}$ \\
\hline
\end{tabular}

${ }^{7}$ Söz konusu fotoğraflar tarafımızca 14.06.2016 tarihinde çekilmiştir. 


\begin{tabular}{|c|c|}
\hline Şalvar & $\begin{array}{l}\text { Yöredeki şalvarların; kadife kumaştan, bol, dökümlü, } \\
\text { canlı renklerin kullanıldiğl ve bele gelen kımın lastik } \\
\text { ile tutturulduğu görülmektedir. Yörede ele geçen } \\
\text { şalvarlarda kullanılan renkler; mor, yeşil, sarı, mavi, } \\
\text { pembe ve yeşildir. }\end{array}$ \\
\hline Önlük-Kırmalı Öynük & $\begin{array}{l}\text { Kadınların gündelik yaşamda iş yaparken elbiselerinin } \\
\text { kirlenmemesi için giyilen üst giyim parçasıdır. Önlükler } \\
\text { genel özellikleri açısından incelendiğinde; kenarlart } \\
\text { firfırlı ve ceplidir. Yöredeki önlüklerde, birbirine zıt üç- } \\
\text { dört rengin tercih edildiği görülmüştür. }\end{array}$ \\
\hline Çorap & $\begin{array}{l}\text { Yörede ele geçen çoraplardaki desenler, "elma şakl” ve } \\
\text { "ekin kellesi" olarak isimlendirilmektedir. }\end{array}$ \\
\hline
\end{tabular}

Tablo 2. Yörede Elde Edilen Bulgular Çerçevesinde Giyim Parçalarının Muhtevası ve Renkleri

\section{SONUC}

Geleneksel kadın kıyafetleri; toplumun örf, adet, gelenek ve göreneklerini anlatan önemli unsurlardır. Bu kıyafetler Anadolu'da yüzyıllar boyunca yaşamış olan uygarlıkların, kültürel birikimlerini, duygu ve düşüncelerini yansıtmaktadır. Ayrıca geleneksel kadın kıyafetleri kültürel etkileşim sonucu şekillenmiş ve kuşaktan kuşağa aktarılmıştır. Toplumun kültürünü, örf, adet, gelenek ve göreneklerini yansitan ve tanitan yöresel giysilerin incelenmesi ve belgelenmesi gelecek kuşaklara aktarılıp yaşatılması açısından önem arz etmektedir. Aşağı Fındıklı Köyü’nde giyim kuşam geleneği, içinde yaşadığ1 toplumun örf ve adetlerine göre şekillenmiştir.

Yapılan araştırmada, geçmişi Orta Asya'ya kadar dayanan bu halkın inanç ve kültürlerini, renk ve motifler aracılığı ile giyim-kuşama aktarıldığı belirlenmiştir. Yörede günlük ve özel günlerde giyilen kadın kıyafetleri hala kullanılmakta olup yöresel giyim kültürünün gelecek kuşaklara aktarılmasına devâm edilmektedir. Ele geçen giysi parçalarının büyük bir kısmı 50 yıldan fazla olup sandıklarda muhafaza edilmektedir. Bunun yanı sıra giysi yapımında kullanılan kumaş parçaları ev tekstili olarak (tepsi örtüsü, kaşıklık gibi) değerlendirilmekte olup dekoratif amaçlı kullanıma dönüştürülmektedir.

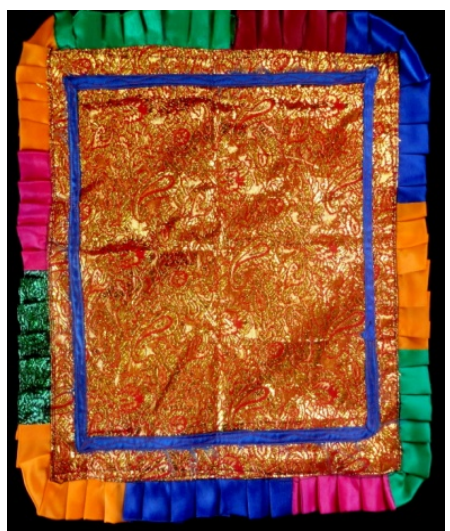

Fotoğraf No:18 Tepsi Örtüsü

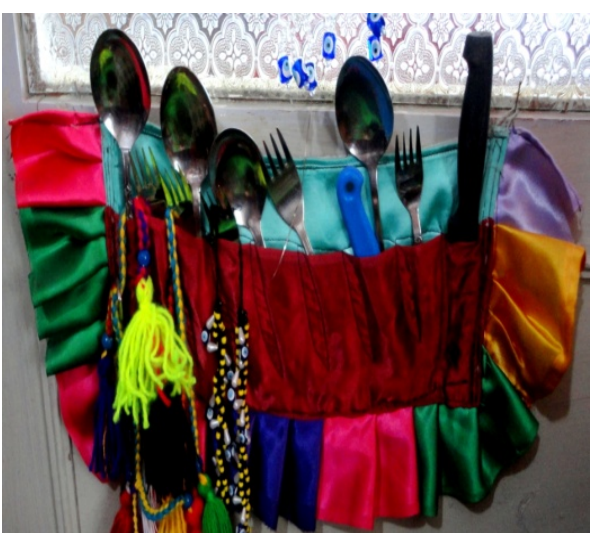

Fotoğraf No:19 Kaşıklık 


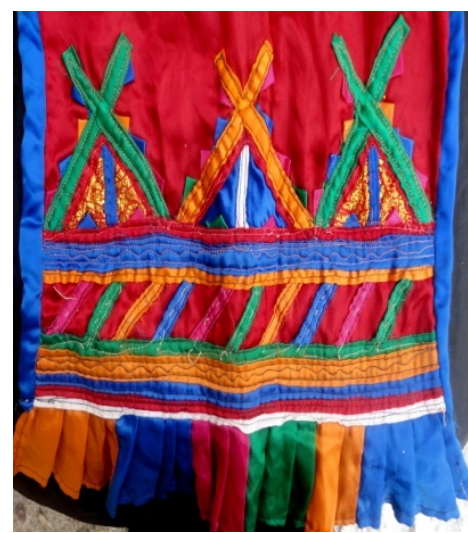

Fotoğraf No:20Yastık Yüzü ${ }^{8}$

Aşağı Fındıklı Köyü giysileri; renk, süsleme özellikleri ve yapımı yönünden farklılık göstermektedir. Örf, adet ve günlük yaşamla ilgili ögelerin kıyafetlere yansıması yöredeki giyim kuşam kültürüne ayrı bir zenginlik katmaktadır. Maddi kültür varlıklarımızdan biri olan geleneksel kadın kıyafetleri; kültürel yapımızı, yaşama biçimimizi en iyi yansıtan ve taşıyan değerler bütünüdür. Fakat tekstil teknolojisindeki gelişmeler, yaşam şartlarının değişmesi, moda-kültür etkileşimi gibi nedenlerden dolayı güncel yaşamda önemini yitirmiş ve kaybolmaya yüz tutmuştur. Bu çalışma; Aşağı Fındıklı Köyü’nde geleneksel kadın kıyafetleri örneklerinin incelenmesi, yörede yaşayan halkın duygu, düşünce ve beğenilerini kıyafetlere nasıl aktardıklarını öğrenmemiz açısından önem taşımaktadır. Bu çalışmanın, hem sanat alanına hem de Çorum yöresini giyim-kuşam bağlamında tanıtımında pratik faydası beklenmektedir.

\section{KAYNAKÇA}

ALTINTAŞ, E. ve D. Çamur: ( 2001).Beden Dili, Ankara, 40, 43, 137.

ALTUN, I.:(2008) : “ Türk Halk Kültüründe Elma”TurkishStudies, International Perdiodical Forthe Languages, Literatureand History of Turkishor Turkic Volume, 3/5 Fall.

CREMERS, İbrahim, W.,: (1976). “Giyim, Kuşam Sözlüğü”, Türk Folklor Araştırmaları, C.16, İstanbul.

BAYAT, Fuzuli: (1993). Oğuz Epik En’enesi ve Oğuz Kağan Dastanı, Sabah: Azerbaycan Elmler Akademiyası.

Evliya Çelebi Seyahatnamesi 3 (2006). Ed. Seyit Ali Kahraman, Yücel Dağlı, İstanbul, Yapı Kredi Yayınları. Kirmiz1,

GENÇ, Reşat: (1996). “Türk Düşüncesi, Davranışı ve Hayatında Renkler ve Sarı,

Yeşil”. Nevruz ve Renkler. Haz. Sadık Tural ve Elmas Kılıç. Ankara: AKM Yay.41-48.

GENÇ, Reşat: (1997). Türk İnanışları ile Millî Geleneklerinde Renkler ve SarıKırmızı-Yeşil. Ankara: TDK Yay.

\footnotetext{
${ }^{8}$ Söz konusu fotoğraflar tarafimızca 14.06.2016 tarihinde çekilmiştir.
} 
GÜNAY, Semra: (2007). “Gelişmekte Olan Çorum Turizmi: Büyük Potansiyel, Yetersiz Tanınmışlık ve Umut Veren Turist Tatmini”, İzmir, Ege Coğrafya Dergisi, Sayı: 16.

HALSE, Albert. O.:(1978). The Use of Color Interiors. 2. Bask1, Mc Graw Hill, Mishawaka, IN, U.S.A.

KAFALI, M.: (1996). “Türk Kültüründe Renkler”, Nevruz ve Renkler, Türk Dünyasında Nevruz

İkinci Bilgi Şöleni Bildirileri, Ankara, Atatürk Kültür Merkezi Yayınları:116, Kongre ve Sempozyum

Bildirileri Dizisi:7, S-49.

LINGS, Martin: (2003). Simge ve Köken Örnek Oluşum Anlamı Üzerine. Çev. Süleyman Sahra. Ankara: Hece Yay.

MANDIRALIOĞLU, Kerim: (2002): Bir Köy; Bir Hikaye Aşağı fındıklı; Efe Cennet, Ankara.

RAYMAN, Hayrettin: (2002). "Nevruz ve Türk Kültüründe Renkler”, Millî Folklor Uluslararası Halkbilimi Dergisi, Y11: 14 Sayı: 53

ŞİMŞEK, Seyfettin, A.:(1963-1964).“Giyim Eşyalarının Hikâyeleri” Türk Folklor Araştırmaları, C.8.

TEZCAN, Mahmut: (1983).“Giyim Olgusuna Sosyo-Kültürel Bakış ve Türklerde Giyim”, Ankara Üniversitesi Eğitim Bilimleri Fakültesi Dergisi, Cilt: 16, Sayı: 1.

UÇAR, T. F.: (2004). Görsel İletişim ve Grafik Tasarım. İstanbul, İnkılap Yayınevi.

YİĞíT, İrfan: ( 2009). Tarihe Işık Tutan Çorum Fotoğrafları, Çorum, Çorum Belediyesi.

http://www.corum.com.tr, 16.10.2016.

\section{KAYNAK KİŞİLER}

Adı Soyadı: Makbule ÇIRAKOĞLU

Doğum Yeri ve Yılı: Aşağı Fındıklı Köyü- 1953

Öğrenimi: İlkokul

Adı Soyadı: Melek KALINSAZOĞLU

Doğum Yeri ve Yılı: Aşağı Fındıklı Köyü- 1955

Öğrenimi: İlkokul 